\title{
A Review of Parliament-Foreign Policy Nexus in South Africa
}

\author{
and Namibia
}

\author{
Adewale Banjo \\ Department of Political Science \& Public Administration \\ University of Zululand \\ KZN, South Africa \\ E-mail: afreb@yahoo.com
}

\begin{abstract}
After a review of selected literature on foreign policy and parliament-foreign policy nexus in South Africa, this article examines the nature of 'Parliamentary diplomacy', with special focus on Parliamentary Committees on Foreign Affairs [PCFA] in South Africa and Namibia since 2000. By means of descriptive approach and content-analysis of documentary sources and conversational interviews, it further explores the extent of executive-legislative frictions over foreign affairs in both countries and the raison deter for parliamentary interest in foreign affairs, which is located within the orbit of National Interest. It argues that the executive-legislature friction over foreign policies may not be resolved sooner, more so that there are other actors seeking to influence the direction of foreign policy in both countries.
\end{abstract}

Keywords: Parliament, Foreign Policy, South Africa, Namibia, Executive-Legislative relations, Parliamentary Committee on Foreign Affairs[PCFAs], SADC, Africa

\section{Conceptual \& Literature Analysis}

As many other political concepts foreign policy is a contested ground, but here it is defined as a framework outlining how the country will interact, relate and do business with other countries and with non-state actors in a mutually beneficial ways and within the context of a country's national interest and economic prosperity. With reference to Parliament, this is considered here as a group of individuals operating on the behalf of others in a binding and legitimate manner and making decision collectively but with formal equality. This definition of the parliament implies a set of key functions: legitimation, linkage, and decision making. A more extended list might include a range of functions such as, governmental oversight, advice and consent, recruitment, cathartic release, arena for debate, exit, patronage, lobby, socialisation, constituency services, selection of the executive, and so on and so forth. These functional and multi-purpose parliaments were the ones that resurged with the Huntingtonian third wave of democratization in the post cold war era. This wave has changed political topography significantly in the third world, at least in context, if not absolutely in content. Accompanying this transformation has been the flourish in parliamentary activism in East, Central Europe and Africa.

As Mathisen \& Tj0nneland [2001] noted, 'we have witnessed a significant institutionalization of legislatures in new democracies in the 1990s' Agh Atila[1995] has also noted that scholarly interest has also expanded, especially those that relates to East and Central Europe. These studies have concluded that legislatures have been important in the democratization process with profound consequences for the political systems in aforementioned regions. However, as noted by Essaiasson,P \& K.Heidar[eds [2000] most studies of parliaments are still focused on the Western experience, and more particularly the experiences of just two institutions: The British House of Commons and the U.S Congress. Arguably fewer studies of parliaments in the developing South are available, compared to the Euro-American axis. In particular, studies on Parliament-foreign policy nexus in Africa can simply be described as very few, again most of these few works are in fact focused on Southern Africa, South Africa to be specific. Indeed there are a number of recent studies on South Africa's post-1994 foreign relations, and the following have been selected to represent the broad range of issues discoursed and debated within this context. This has also been further sub-divided into two groups viz; the Foreign-Policy-focused literature and the literature addressing the role of the Parliament in foreign policy.

\section{Literature Review}

With specific reference to South Africa's foreign policy in the post-apartheid era, Philip Nel[1996] has examined the role of civil society in the promotion of human rights through the mechanisms provided by foreign policy, while William J Foltz's[1996] work on the foreign policy of the new South Africa gives a brief description of foreign policy under the apartheid regime, and then looks at the state departments and institutions under the new SA government which are and will be actors to formulate foreign policy for the future. Raymond Suttner[1996] tries to explain the 
difficulty SA faces in trying to promote human rights and democracy, while simultaneously trying to build bilateral and multilateral diplomatic relations with countries known for human rights violations. The study suggest that SA may have a capacity to act as a type of role model, but that it needs to weigh decisions on a case by case basis. Another Raymond Suttner 's[1996] work on Foreign policy of the new South Africa: a brief review, comments on the 'near-existence' of foreign policy in the new South Africa, and describes who the main actors in foreign policy are, how they are coordinated, the status of the multilateral relations, civil society and its organs, the problems with human rights, the question of identity, and the commitment of foreign policy to democracy in this new dispensation.

Still in the 90s Greg Mills [1997] warns about the variety of roles that SA perceives itself in and the limitations the country has to contend with in its position between the West and Africa, having an option to play an expanded role in Africa and the risk that regional involvement will detract from domestic imperatives. The study addresses the main objective of SA's foreign policy, strategies to adopt to achieve it, and the attributes needed to ensure that correct policies are adopted and followed. Again, Greg Mills[1996] in his South African foreign policy: the year (1996) in review, states that, since April 1994, South Africa foreign policy has attempted to steer a neutral path, and concentrated on 'universality', expanding SA representation abroad, and increasing diplomatic presence in South Africa. Greg Mills contends that the 'New South' concept may revitalize a foreign policy which lacks overall direction, is over focused (and under spent) on Africa, and has organizational difficulties causing it to have a bad name. The 1996 review further advises that foreign policy should rest in the hands of elected officials and policy professionals rather than in the hands of the Presidents advisors. In a study by Roland Henwood [1997] he divides the development of SA`s foreign policy into two phases: National Party rule (1948-1994) and ANC led government (1994-), including the transition period of 1990 to 1994 which formed the foundation of post - 1994 foreign policy. The study details aspects of both periods, and continues with a brief look at foreign policy formulation and implementation, as well as SA's relations with the 'problematic' states such as Cuba, Libya, Iran, Syria and Peoples Republic of China

Greg Mills`s[1997] briefly reviews the successes SA achieved in the field of foreign policy, and look at problems encountered, and the restructuring of the Department of foreign affairs (DFA). The review gives attention to the interpretation of foreign policy, identification of priorities, budget, the importance of foreign economic relations, the regional dimension, and, SA in Sub Sahara Africa

In Anthoni van Nieuwkerk's [1998] study on South Africa's emerging Africa policy examines the emerging Africa posture of the post-1994 South African government, focussing the discussion of foreign policy in the new South Africa around four themes: the views of foreign policy makers in Pretoria, the views of analysts and critical scholars, the fact of African reality, and, foreign policy insights gained from the discussion. Denis Venter `s[1998] South African foreign policy in the African context points out that South Africa's foreign policy has gone (and is still going) through a process of profound change, and that the dimensions of its relationship with Africa are likely to focus on issues such as socio-economic development, trade, technical aid, migration, resource management and ecological concerns rather than on narrow military security issues.

Greg Mills[1998] updates an earlier and abridged version of this chapter published in 1997, to identify the main foreign policy tracks followed in SA since 1994. Greg posed the following questions; what the main overriding objective of the policy is, what strategies to be followed to achieve it, what tactics to be followed to steer it towards ensuring that correct strategies are adopted and followed, and what other factors will shape the pursuit of this policy

In Greg Mills`s [1999] South African foreign policy in review, the Asian currency crises, the 'millennium bug', proliferation of weapons, and continuing instability in parts of southern Africa were identified to have dampened the high hopes of a true African renaissance in post cold war, post apartheid Africa. Greg situates SA`s foreign policy in international and regional context, and suggests that rationalization and cost cutting will be necessary, especially in view of global events.

Zondi Masiza [1999] also argues that the political parties that contested the June 1999 elections in South Africa, hardly raised foreign policy as an issue. He tries to explain the silence on foreign policy issues during the elections and asks if South African public opinion on foreign policy is strong enough to influence its direction at all. But Jakkie Cilliers[1999] provides a broad framework for reviewing South Africa's emerging foreign policy identity on the eve of the second elections in June 1999 and the turmoil that has come to characterize much of the African continent in recent years. Jakkie points out that without stability there will only be war, poverty and continued marginalization of Africa, and no chance for economic development and growth. Philip Nel [1999] conducts two separate surveys on the foreign beliefs of South Africans, based on the same questions, for 'mass opinion' on the one hand and 'elite opinion' on the other hand. The study shows that South Africans are much more concerned about domestic problems than they are about foreign policy issues. The study briefly discusses the decision by the South African government to establish full diplomatic relations with the Peoples Republic of China (PRC) and to break ties with Taiwan (ROC).

John Seiler [2000] in his towards fresh perspectives in South Africa's foreign policy analysis, critically assesses Francis Kornegay and Chris Landsberg`s[2000] claims that South Africa's foreign policy is dominated, to its detriment, by the 
old guard. Suggest a different set of assumptions to support in public analysis the formulation and carrying out of South Africa's foreign policy. Bronwen Manby [2000] sets out the inconsistencies between theory and practice in South Africa's foreign policy, in relation to issues of human rights. The study further outlines the seven principles of South Africa's foreign policy and focuses on South Africa's foreign policy in practice (human rights regime, peacekeeping, bilateral relations with East Asia, Nigeria and Lesotho, and arms sale). The study concludes that while South Africa's theoretical commitment to human rights has been fully realized, it is not the light that guides the Department of Foreign Affairs (DFA).

Audie Klotz[2000] in Migration after apartheid: deracialising South African foreign policy, argues that the status in South African immigration policy derives from identity politics, rather than embracing the outside world, deracialisation, xenophobia now prevails. The study concludes that the rising tide of xenophobia against the influx of fellow Africans creates a potent barrier to reforms in immigration policy. Vincent Williams[2001] also points out that bilateral, multilateral and/or regional agreement between countries in Southern African region tend to focus on cooperation in the economic and security spheres. The labour environment, however, highlights the marked discord between South Africa's pronounced foreign policy objectives and its domestic migration policy and legislation. The study discusses the efforts to draft a regional migration protocol, the suspension of the SADC Draft Protocol on Free Movement in 1999, and the White Paper on International Migration, to ask what the link is between foreign policy and migration policy.

Maxi Schoeman[2002], contends that it is South Africa's (and Africa's) position in the global political economy that is presently occupying the mind of its foreign policy makers. The study briefly looks at South Africa's foreign policy objectives, structures and strategies, the prerequisites needed to enhance its international status and then touches upon initiatives such as the renaissance idea, the NAI or MAP initiative, and drawbacks experienced.

Maxi Schoeman and Chris Alden [2003] provide an overview of South Africa's quiet diplomacy towards Zimbabwe. In order to understand the constraints placed on South Africa's policy actions. The study explores the role and actions of the international, mainly Western community and the foreign policy behavior of African countries. The study also deals with an analysis of the constraints on South Africa's policy making. Another example of a seminal work on post-1994 SA Foreign policy is the Chris Alden \& Garth Le Pere's[2003] Adelphi Paper, which provides a succinct analysis and assesses South African foreign policy from the onset of the democratic transition to 2003 and focusing on the question of South African leadership in the context of this transition.

Chris Landsberg and David Monyae[2006] also reviews how South Africa's principal foreign policy actors define the countries international role conceptions and discuses the countries view of its global role. The study considers seven south Africa-specific international roles, namely voice, example setter, mediator-integrator and regional sub-system collaborator, the diplomat, bridge builder, activist multilateralist, and faithful ally.

Studies on Parliament-Foreign Policy Nexus: With reference to parliament's role in foreign policy making in SA there a very few studies in this area. Some of the available sources include Parliament and foreign policy by Raymond Suttner [1996] which debates the question of whether parliament should be concerned with formulation of foreign policy or not, and discusses the situation in South Africa after April 1994, where as yet no institutionalized mechanism exists whereby a creative relationship between the department and the portfolio committee concerned with foreign policy can be formed. In her work Jo-Ansie van Wyk[1997] deals with the broader context of SA's external relations in 1996. The work is organized around the activities of parliamentary bodies and instruments concerned with foreign policy issues, and the influence, if any, of these institutions on foreign policy decision making. Tim Hughes [2001] has outlined the role played by the parliamentary portfolio committee on foreign policy (PCFA), summarizing its activities for the year 2000-2001, and provides a brief evaluation of the performance of the committee. The author asks whether the committee is doing enough and concludes with recommendations for its functions in the future

Jo-Ansie van Wyk [2001] provides a frank view of structures and procedures involved in foreign policy making in South Africa, especially from 1999 to 2 June 2000 elections. Again Tim Hughes [2005] examines the process and exercise of democracy in all the parliaments of the region. Tim Hughes tries to contribute to strengthening parliamentary democracy throughout Southern Africa and makes recommendations on how its application and implementation in each country can be improved, strengthened and sustained. Philip Nel and Jo-Ansie van Wyk[2003] examines some of the ostensible public participation deficiencies encountered in foreign policy making in South Africa. The authors argued that the citizenry of South Africa is largely excluded from decision making on public policy issues beyond the boarders of their state. This contributes to their disempowerment in the face of seemingly inevitable and anonymous forces of globalization, and adds to their alienation from and apathy towards foreign policy.

In summary, there is no doubt that the selected studies under review deal extensively with the core of South Africa's foreign policy in terms of options and actions and to certain extent the role of the parliament. However, there has been no significant comparative study of at least two similar countries in southern Africa to show if the experiences of 
developing or new democracies differ or are similar, and to what extent within this context, and in what way[s] can these common experiences be managed in the interest of deepening democratic practices and processes.

\section{Motivation \& Methodology}

As noted earlier, the most important observation or gap is that quite a number of studies on South and Southern Africa's parliament have not compared experiences of similar countries in SADC with specific reference to Parliamentary role in foreign affairs, either as a critical part or as consistent opposition to executively determined policies. Thus a comparative study of two similar post-1990 prime democracies in Southern Africa which intend to show the quality of executive-legislature cordiality [or otherwise] over foreign affairs cannot but be regarded as very significant enterprise. Therefore the overriding motivation for this study is broadly to add up to the now growing literature on parliamentary activism in Southern Africa. Specifically, the study holds the promise of graphically describing the role and relevance of South Africa and Namibia 's third wave parliaments in foreign affairs vis a vis their relationship with the executive, and by extension utilising the window of opportunity it provides to measure the texture and the state of health of democratic institutions in Southern Africa. It is against this background that this study is designed to answer the following questions:

First, what is the role of PCFAs in the legislature of South Africa and Namibia, and what are the similarities as well as differences in the attitudes and practices of both PCFAs towards foreign policy issues? Second, what are the challenges that have faced, and still facing either or both parliaments, with reference to executive-legislative relations over foreign affairs? Finally, in addition to constitutional mandate, what is the other reason[s] for parliamentary interest in Foreign affairs?

With regards to sources of data and methodology, data were predominantly sourced from primary sources such as the media reports, library and personal interviews with the actors/MPs/the member of Foreign Affairs Committee in both Parliaments. This approach helps to take advantage of the benefit of current history and political process in the ways they have unfolded and interacted. Again, it has helped also to see clearly why and how parliamentarians in Namibia and South Africa have engaged or have not been involved [as they would have wanted to] in diplomatic matters and foreign affairs overtime.

\section{Parliament and Foreign Policy in South Africa and Namibia}

Given the history of long struggle for liberation in both South Africa and Namibia it is not surprising to discover that both countries foreign policy objectives reflects the desire to advance the cause of peace, freedom in Africa and by extension the international community. According to Namibia Constitution[1998] article 96 highlighted the country foreign policy objectives as follows: 'The State shall endeavour to ensure that in its international relations to: [i] adopts and maintains a policy of non-alignment; [ii] promotes international peace and security; [iii] creates and maintains just and mutually beneficial relations among nations; [iv] fosters respect for international law and treaty obligations; [v] encourage the settlement of international dispute by peaceful means' . In the case of South Africa, the Foreign Policy Discussion paper[1996] which is retrievable from the government website outlines principles which serve as guidelines in the conduct of South Africa's foreign relations. These include: [i]a commitment to the promotion of human rights; [ii]a commitment to the promotion of democracy; [iii]a commitment to justice and international law in the conduct of relations between nations; [iv] a commitment to international peace and to internationally agreed-upon mechanisms for the resolution of conflicts; [v]a commitment to the interests of Africa in World Affairs; and[vi] a commitment to economic development through regional and international cooperation in an interdependent world."

Hence such critical concern such as the State's external relations is of paramount interest to all parliaments. Even then, this engagement of the legislature with foreign affairs and the whole range of activities of the legislature that criss-cross the terrain of external relations and engagement with diplomatic community, aptly described here as "parliamentary diplomacy" is also not the job of the whole house in any representative democracy. Representation is one of the hallmarks of modern democracy and the arm/organ of the state that most illustrate this assertion is the parliaments/legislature. In South Africa and Namibia the two countries that both became independent in the 1990s have adopted bicameral legislature. The Namibian National Council consisting of 26 members is the Upper Chamber, while the National Assembly which is the lower house has 78 members. But South Africa has a total of 490 Parliamentarians, with National Assembly consisting of 400 members, while the National Council of Provinces [NCOP] has 90 members.

A division of responsibilities and competencies, with checks and balances built into the political system to prevent the abuse of executive powers, is a feature of all liberal democracies, whether parliamentary, presidential or some sort combination of the two. Thus one key role of the legislature is to check, challenge, monitor and legitimize policies undertaken in the name of the state by the executive branch of government. Indeed, it could be argued that, if there is no tension between a parliament and the executive, the former is not performing its proper role. Specifically there are Parliamentary Committees on Foreign Affairs [PCFAs] that often created to deal with issue of foreign relations and international/diplomatic affairs. 
In South Africa and Namibia there are Parliamentary Committee on Foreign Affairs [PCFAs] which though vary in numerical strength and issues and concerns covered, they all took cognisance of the multi-party nature of both countries. The Parliamentary Committees on FA in both countries reflect the political parties in Parliament, but in proportion to their percentage in the whole house. This practice also applies within the context of gender-mainstreaming. In South Africa, Thirty three percent [33\%] of the Joint PCFA are women, while in Namibia; Twenty seven percent [27\%] are women.

The Role of PCFAs in South Africa and Namibia: Globally parliaments had been widely expected to decline in significance in the later part of the twentieth century, but instead they have developed new and vital political roles and have innovated in their institutional structure-most currently in newly organised or invigorated parliamentary committees, not only in a few parliaments, but across most political cultures and systems. Even as newly democratic parliaments throughout Africa experiment with elaborate committee structures, those with older highly developed committee system are reaching for more varied and flexible alternatives. In short parliamentary committees have emerged as vibrant and central institutions of democratic parliaments of today's Africa. Further in most parliaments PCFA is one of the fundamental portfolio committees, and hardly can we find any country's parliament in Africa without a PCFA. This is predicated on the nexus between national interest and foreign affairs as a major platform to advance the same. Thus in Namibia, the duty of the parliamentary standing committee on foreign affairs, defence and security is to: [i] Consider any matter it deems relevant to defence; home affairs; foreign affairs; Namibia central intelligence service (NCIS) and prisons and correctional services; [ii]Consult and liaise with such offices, ministries and agencies as necessary; [iii] Exercise oversight function with regard to Namibia's foreign policy and its relations with other states on matters of defence and security ; [iv]Investigate issues relating to the policies, standards and procedures followed by the Namibian central intelligence service; and [v] Probe issues relating to human right violations; obtain information from government or other sources regarding any real or perceived threat to the security of the republic of Namibia; enquire into and monitor international Protocols, conventions and agreements that may affect Namibia's foreign policy, defence and security, and where necessary, make recommendations to the national assembly._

In South Africa, Tim Hughes [2002] has argued that the PCFA is fundamentally created and tasked with maintaining oversight of:

-the exercise of national executive authority within the sphere of foreign affairs

-the implementation of legislation pertaining to the spheres of foreign affairs

-any executive organ of the State within the sphere of foreign affairs; and any other body or institution in respect of which oversight was assigned to it.

The PCFA also enjoys considerable specific powers. It may monitor, investigate and make any recommendations concerning any constitutional organ of state within its purview. The committee is granted such powers with regard to the legislative programme, the budget, rationalisation, restructuring, functioning, structure or staff and policies of any organ of state or institution. Furthermore, the committee is to consider all bills and amendments to bills referred to it. A further role unique to the PCFA is the consideration and approval of all international conventions and treaties prior to their ratification by Parliament. In the new millennium, the means of engagement and involvement remain largely the same as before and these include the following:

Briefing and Question time: Briefing is an age old mechanism for parliamentary involvement in foreign affairs. It also includes parliamentary sessions on debates, briefings, question time and press releases. In South Africa the first PCFA briefing session in the new millennium was held on the $3^{\text {rd }}$ of February 2000.Indeed the first four PCFA sessions were primarily for briefing, which includes the [i] Briefing by P.Hain, the British Minister of State for Foreign \& Commonwealth Affairs on 3rd February;[ii] Briefing by the Minister on South Africa Activities in Africa on 15 February[iii] Budget briefing on $1^{\text {st }}$ March 2000 and [iv] Briefing on the Indian Ocean Rim on 8 March 2000.

Between $3^{\text {rd }}$ February 2000 and $1^{\text {st }}$ June 2008, there are about one hundred and ninety [190] entries with reference to documented activities or meetings of the Joint Parliamentary Committee on Foreign Affairs [PCFA]. However almost one hundred and fifteen [115] or about 57 percent of these were briefings and reporting/question time sessions. In terms of regularity the Parliamentary Committee on Foreign Affairs in South Africa is relatively active with about four meetings/ press releases per month. The subject matter seems also to weigh heavily in favour of African issues, which claims almost forty [40\%] percent. This is not unconnected with South Africa's new role in Africa as political gladiators as well as a major player in Africa's new and emerging market for foreign direct investment. More so that the executive sector of government seem to be leading the African renaissance project in the wake of the transformation of OAU to AU in Durban in 2002.

But in Namibia the entries from 2004 to 2008 contains only one item that deals directly with the issue of foreign affairs. Hence it is argued that there is no better evidence to proof that there is a kind of low-level parliamentary diplomacy in Namibia. Almost all external and foreign matters were exclusively dealt with by the executive. With specific reference 
to the activities of the Parliamentary Committee responsible for foreign affairs, Security and Defence, the Committee only reported on its visit to the hardship mission in March 2005.The three other reports between 2004 and 2006 were all about the defence component of the committee's responsibilities. These reports includes the Report on the visit to military installation [2005], the Report on the motion on the increase in criminal activities and violence on innocent and vulnerable Namibians [November 2006], and the Report of the committee on visits to police stations/cells, prisons, border posts and military installations in the North-east and southern regions in 2006

Visitation/Representation/Fact-finding Missions: This is another means by which the Parliaments particularly the PCFAs all over seek to play an active role in the monitoring of national interest that borders on foreign affairs. In Namibia the National Assembly's standing committee on foreign affairs, defence and security visited some Namibian diplomatic mission classified as 'hardship missions' in July 2007. It was reported in the [Parliament Journal, 2007] that the committee members discussed with head of heads of missions, their staff (both Namibian and locals) about the difficulties that they experience in fulfilling their duties. The committee looked at the following issues that affect Namibian hardship missions: economic situations; security situations; effectiveness of communication with the host country; water and electricity supply; education; health and accommodation.

In South Africa PCFA is regarded as a 'mobile committee', because the members of committee travel often on missions, going by the nature of its mandate. As a result there are numerous reports of visitation to other countries and fact-finding missions. However to what extent these reports are fed into executive decisions on those issues are still very hard to ascertain. Thus in the following section the article tries to explore the nature of executive-legislative friction over foreign affairs in South Africa and Namibia since the beginning of the new millennium.

\section{Evidence of Executive-Legislative Friction over Foreign Affairs}

After a series of conversational interview with a number of parliamentary actors and observers in Namibia and South Africa, it became very obvious that there is a kind of low-level legislative-executive friction over the conduct of foreign affairs in both countries. There a number of indicators to illustrate this point and these include:

Complaints over Budget and Foreign Policy Process: First, the budget of the Ministry of Foreign [MFA] affairs in Namibia and Department of Foreign Affairs[DFA] in South Africa in practice do not get scrutinised by the PCFAs and the committee is seldom consulted on the same issue. This often draws the flak of the PCFAs in both countries. The crux of the friction is that the PCFA's budget remains the prerogative of the executive in both countries. With specific reference to Namibia, the PCFA do not provide opinion and the estimates submitted often get jettisoned or not considered most of the times. According to the PCFA Clerk interviewed in Windhoek, [who had worked at the National Parliament for twelve years], "most of the times, to the surprise of the PCFA the actual allocation only gets known on the floor of the whole house or worse still on pages of newspapers'[Personal Interview, November 2007]. Secondly, anecdotal evidence suggest that the PCFA do not get to input on foreign policy both at the design stage and are often not involved at the implementation level. The Clerk interviewed further provided evidence to corroborate this point. According to the Clerk, 'I don't remember when the PCFA get invited by the Ministry of Foreign Affairs [MFA] for discussion on any foreign policy issue....no control at all and yet only PCFA is mandated to do this..' [Personal Interview, November 2007]

The Clerk of the PCFA further revealed that "it was not until 2006 when there was a major uproar about military-related incident in the Northern part of Namibia, that the PCFA \& Defence began to directly make recommendations'[Personal Interview, November 2007]. On the part of the executive the PCFA visits to Namibia embassies [hardship mission] abroad, though it relates to oversight functions of the PCFA, yet this exercise seem to have attracted serious reservations and complaints from the executive arm of government. The PCFA was perceived as interfering in the business of administering the country's foreign affairs.

Limited Role in Envoy Nomination \& Deployment: With reference to Ambassadorial selection and posting the PCFAs in both countries feel sidelined. The PCFAs also often complain that they have very limited, if any, role in the selection and deployment of Ambassadors, High Commissioners and Consul-Generals. Evidence gathered also suggests that the PCFAs do not often have opportunity to scrutinise the credentials as well as integrity of the would-be envoys before posting. This is a profound concern, yet the PCFAs could not do much within this context, because this practice and responsibility is not regarded as a constitutional mandate. Again, apart from seeking involvement in the selection, scrutinising and ratification of South African and Namibia's envoys going abroad, the parliament should also be a major place for courtesy calls by incoming foreign diplomats soon after presentation of their letters of credence. It is further argued that because of the significant status, the legislature enjoys in any democratic governance, departing envoys should recognise this role and ensure to appreciate the need to include the parliament in their farewell tours. This seems not be a common practice as yet in Namibia and South Africa, though there are exceptions. For example, the Parliament Journal, 2007 recorded the farewell visit of the U.S Ambassador to Namibia, Ambassador [Mrs] Joyce Barr when she paid a courtesy visit to the Speaker of the National Assembly Hon.Dr.Theo-Ben Gurirab on 17 July 2007 to bid farewell to the Parliament. 
Limited role in the ratification of treaties, conventions and protocols: After a rigorous content-analysis of the various Annual Reports released by the Namibia's Ministry of Foreign Affairs[MFA] and South Africa's DFA, it became obvious that it is actually in theory that both Parliaments are supposed to advise government on ratification of international treaties and conventions. With specific reference to Namibia, most of the treaties signed between 2005 and 2006, from Stockholm Convention on Persistent Organic Pollutants, to the Agreement Concerning the Treatment of War Graves of Members of the Armed Forces of the Commonwealth in the Territory of the Republic of Namibia did not enjoy any significant verification or contribution from the parliament. Rather the Attorney-General of the Republic of Namibia seemed to have been the preferred partner on these international matters. In fact, the MFA Annual Report [2006] noted that 'The Attorney-General being the principal legal adviser to government approves all the principal bilateral and multilateral agreements before they are entered into'

Decision on strategic matters without recourse to PCFA: In the late 1990s troops or peace-keeping force were sent from Namibia, to intervene in the DRC conflict and specifically to support the Kinshasa regime, led by Laurent Kabila, until he was assassinated by Congolese armed rebels. This action led to mild friction between the executive and the Legislature based on the argument that, the executive cannot send the military out on such a sensitive and high risk missions without the consent of the citizenry through the parliament. Another example of this limitation in the new millennium relates to the inability of the parliament to engage in debate that will lead to government position on UN Reforms: While the debate on UN reforms lasted with reference to African representation and position on the issue, the Namibia legislature did not officially discuss the issue nor were the parliamentarians able to offer any advise with reference to official government position. However, unlike the self-imposed or executively-orchestrated limitation experienced by the parliament the, executive arm of the government issued a statement on the subject-matter in September 2005. Isaak Hamata[ 2006] in his piece reported how President Hifikepunye Pohamba in his address to the $60^{\text {th }}$ General Assembly of Heads of State and Government pledged Namibia's willingness to assist in the democratisation of the world body. The President further stated 'if the UN is to continue serving the interests of the world, it needed to be reformed.......we must be guided by the very principles of democracy, equity, justice and fairness for all. At the centre of this overdue exercise must be the compelling need to better serve all peoples, regardless of their race, religion or status of development'.

Documentary sources and personal interviews have established the fact that South Africa under Thabo Mbeki sought to promote economic justice and redesign a fairer global North-South relations. In the new millennium presidential diplomacy was at work when at various international forums the former president of South Africa harped on the importance of debt relief and elimination of poverty in Africa. In June 2002, it was the president that presented NEPAD to the G8 in Kananaski/Canada on behalf of Africa, and in August/September South Africa hosted the UN World Summit on Sustainable Development. By June 2003 President Mbeki had handed over the chairmanship of both the Non-Aligned Movement [NAM] and the African Union, but his government continued to devote much attention towards resolving the conflict in the Great Lakes region. Again since South Africa took up a non-permanent seat at UN Security Council, the country has tried to present and pursue the African agenda, though it has also come under intense international criticisms for voting not to take a stand against human rights abuses in Myanmar and opting for quite diplomacy approach towards Zimbabwe. The central argument here is that, most of the initiatives above were presidential in nature, from conceptualisation to implementation. In other words, from the NEPAD idea to how South Africa voted on the Security Council, the executive/presidency was completely in charge.

From the foregoing, as much as the parliament desires to be involved in Foreign affairs the South African and Namibian experiences have shown that 'presidential diplomacy' often supersedes 'parliamentary diplomacy'. i.e the executive arm of government have pre-eminently being in charge of the business of managing the foreign and diplomatic relations of both countries. But what informs Parliamentary interest in Foreign affairs? This question will be addressed in the next segment of this article.

\section{Explaining Executive-Legislative Friction over Foreign Affairs}

In addition to constitutional requirement, why do parliamentarians seem to be interested in Foreign Affairs and how diplomatic business is conducted in any democracy? By means of conversational interview in both countries, it has come across that the idea of national interest is very central to the raison d'etre for parliament-executive friction over Foreign Affairs. Although the term national interest is somewhat ambiguous, one can agree with Peter Shearman [1997], who usefully defines it in terms of the common good of a society within the bounds of a nation-state. That is to say, although between groups in domestic society there are conflicting interests, there exist general and common benefits to society that all members share irrespective of individual or group preferences on other issues. The basic common interests of any state are survival for itself and its population, maintaining the territorial integrity of the state, and enhancing its status and position in relation with other states. Conceptions of the national interest provided a powerful dynamic for mobilizing domestic society around specific political programmes and issues. A constant feature of 
domestic politics in all types of pluralist political systems is competition between political groups to be seen as the one group that offers the best safeguard for maintaining national interests.

National interests are linked to perception of identity. Images of a nation and its place in the world can be drawn upon to mobilise what William Bloom[1990] refers to as a 'national identity dynamic' with government and opposition groups drawing upon, creating, and manipulating these images for their own ends in a struggle for political power. The assumption here is that political elites manipulate a social-psychological dynamic relating to a conception of national identity which is itself determined by the external environment. In other words conception of the national self are linked to perceptions of the external other. Without taking this socio-psychological argument too far, these idea of national identity linked to national security and perceptions of the international environment are useful for understanding the executive-legislative hassles, though at low-level, over foreign affairs in South Africa and Namibia in the new millennium.

Foreign policy and diplomacy can be viewed as the means to ensure the objective of defending national interest and, hence, simultaneously the strengthening of national identity. Foreign policy also provides, as Philip Cerny [1979] has put it: "the specific instrument par excellence at the disposal of elites hoping to mobilise the population of a legally-recognised nation state towards legitimation and political integration'. There are four important reasons why foreign policy and competing conceptions of national interests should be so powerful in the mobilisation of domestic society.

First, national interests are universal interest shared by all members of the society, transcending other cleavages based upon ethnicity, religion, culture, or class. Hence political groups are provided with the most potent force for mobilising the widest possible sections of the society.

Second, foreign policy provides a perfect discourse of politics that allows for escape from objective verification. Unlike specific economic or social policies, the feature of foreign policy, designed to defend the national interest, are removed from the same standards of immediate or short-term tests that can easily lead to failure.

Third, foreign policy is often more emotional as an issue affecting society, but it is often far more remote in terms of its impact on the individual. As an emotive issue the mass national public will always react favourably to policies which seem to enhance the national interest, and negatively to policies which seen as undermining it.

Fourth, foreign policy facilitates, much more readily than domestic policies, opportunities for the emergence of strong and charismatic leaders, who, rapping themselves in the national flag and the rhetoric of national identity, portray themselves as the only effective defenders of the national idea.

\section{Conclusion and Summary}

In conclusion, the inability of the parliaments to influence the executive often on strategic diplomatic matters and the seeming second fiddle on foreign affairs may be of course due to one other reason. In addition to constitutional limitations, another reality is the multiple actors and forces exacting influence of the executives in this age of globalisation. The role of other actors, such as foreign powers, opposition political parties, the civil society/third sector and the media, are as crucial as that of national parliaments if not more. These other actors do influence the State behaviour more often than imagined and they can be extremely strong in pushing agenda through the executive arm of government. Sometimes this is being done by literally arm-twisting the executive in technical negotiations.

In summary the study has established the fact that the post-1990 broad-based and all inclusive democratic governance in Africa, with specific reference to Namibia since 1990 and South Africa in 1994, also incorporates as well a great deal of parliamentary activism. We have been able to establish that foreign policy is always a contested ground between executive and legislature, with the latter always [even in developed democracies] coming through as playing second fiddle in foreign affairs. The study located the attractiveness of foreign affairs both to the parliament and executive within the orbit of national interest, as defined by policy elite. The article further describes the parliamentary approach to participating in foreign affairs through the PCFAs. The article argues that though the PCFAs are tasked with specific oversight responsibilities relating to foreign affairs are nevertheless often find it difficult to do enough or do more. The study utilises several indicators to illustrate the PCFA/Parliament's frustration with the executive over foreign affairs administration. In conclusion, the article noted the factor of multiple actors as one reason the parliament-executive friction over foreign affairs may not be resolved soon.

\section{References}

Agh Atila. (1995). The Experiences of the First Democratic Parliaments in East Central Europe' Communist and Post-Communist Studies Vol.28, no2, pp203-214.

Annual Report. (2006). Ministry of Foreign Affairs, Republic of Namibia, p.43.

Anthoni van Nieuwkerk. (1998). South Africa's emerging Africa policy in Garth Le Pere [et al] South Africa and Africa: reflections on the African renaissance, 1998, p 42-49. 
Audie Klotz. (2000). Migration after apartheid: deracialising South African foreign policy, in Third World Quarterly, v 21, no 5, Oct 2000, p 831-847.

Bronwen Manby. (2000). Human rights and South Africa's foreign policy: a guiding light or flickering candle? in South African Journal on Human Rights, v 16, no 2, 2000, p 372-401.

Chris Alden and Garth. (2003). Le Pere. South Africa's post apartheid Foreign Policy-from Reconciliation to Revival?/ Adelphi Paper, 2003. number 363. Oxford University Press.

Chris Alden and Gatrh Le Pere. (2003). South Africa`s post-apartheid Foreign Policy-from Reconciliation to Revival?/ Adelphi Paper, no 363.Oxford University Press.

Chris Landsberg and David Monyae, South Africa's foreign policy: carving a global niche, in South Africa Journal of International Affairs, v 13, no 2, Winter/Spring 2006, p 131-145.

Denis Venter. (1998). South African foreign policy in the African context in African Currents, vol 15, no 26, Oct 1998, p 14-63.

Essaiasson,P \& K.Heidar[eds]. (2000). Beyond Westminster and Congress. The Nordic Experience, Columbus: Ohio State University Press.

Greg Mills. (1998). South Africa's foreign policy: from isolation to respectability? in David Simon [edited] South Africa in Southern Africa: reconfiguring the region, 1998, p 72-86.

Greg Mills. (1999). South African foreign policy in review (1998-99), in South African yearbook on international affairs, 1998/99, p 1-20.

Greg Mills. (1997). Learning all over the places? : the not-so-new South Africa's foreign policy in Fairy godmother, hegemon or partner?, 1997, p 19-34.

Greg Mills. (1997). South Africa's foreign policy: the year in review in, South African yearbook on international affairs, 1997, p 1-17.

Greg Mills. (1996). South African foreign policy: the year in review in South African yearbook of international affairs, 1996, p 1-8.

Isaak Hamata. (2006). 'Democratising the UN: Namibia Supports the African Position' in Namibian Review, Jan/Feb, 2006 p37-38.

Jakkie Cilliers. (1999). An emerging South African foreign policy identity? in Africa Quarterly, v 39, no 1, 1999, p 41-68.

Jo-Ansie van Wyk. (1997). Parliament and foreign affairs: continuity or change? 1997, p 189-213 South African yearbook of international affairs.

Jo-Ansie van Wyk. (2001). Power house or rubber stamp? : Parliament and foreign affairs South African yearbook of international affairs, 2000-01 / SAIIA, 2000-2001, p 83-90.

John Seiler. (2000). Towards fresh perspectives in South Africa's foreign policy analysis in Africa Insight, v 29, nos 3-4, Jan 2000, p 34-35.

Mathisen, H W \& Tjonneland. (2001). Does parliament matter in new democracies? The case of South Africa, 1994-2000. Bergen: CMI .

Maxi Schoeman. (2002). Objectives, structure and strategies: South Africa's foreign Policy in South African yearbook of international affairs / South African institute of international affairs, 2002, p 73-84.

Maxi Schoeman and Chris Alden. (2003). The hegemon that wasn't: south Africa's foreign policy towards Zimbabwe in Strategic Review for Southern Africa, v 25, no 1, May 2003, p 1-28.

Parliament Journal, May -August. (2007). Windhoek, Namibia Personal Interview with the Clerk of the PCFA D\&S in November.

Peter Shearman. (1997). 'Defining the National Interest: Russian Foreign Policy and Domestic Politics', in Roger E.Kanet \& Alexander V.Kozhemiakin[eds], The Foreign Policy of the Russia Federation, Macmillan UK Press Ltd.

Philip Nel and Jo-Ansie van Wyk. (2003). Foreign policy making in south Africa: from public participation to democratic participation, in Politeia, v 22, no 3, 2003, p 49-71.

Philip Nel. (1996). Civil Society and the transnational promotion of human rights in Through a glass darkly? : Human rights promotion in South Africa's foreign policy. 1996, p 44-55.

Philip Nel. (1999). The foreign policy beliefs of South Africans: a first cut in Journal of Contemporary African Studies, v 17, no 1, Jan 1999, p 123-146. 
Philip.G.Cerny. (1979). Foreign Policy Leadership and National Integration' British Journal of International Studies, vol 5.p.71.

Raymond Suttner. (1996). South African foreign policy and the promotion of human rights,1996, p 16-22.

Raymond Suttner. (1996). Foreign policy of the new South Africa: a brief review 1996, p 191-205.

Raymond Suttner. (1996). Parliament and foreign policy South African yearbook of international affairs, 1996, p 136-143.

Roland Henwood. (1997). South Africa's foreign policy: principles and problems, in Fairy godmother, hegemon or partner? 1997, p 3-18.

South African Foreign Policy/Discussion from http://www.info.gov.za/greenpapers/1996/foraf1.htm\#B/ on 3/6/2008].

The Constitution of Namibia. (1998). Windhoek, Namibia.

Tim Hughes. (2002). The parliamentary portfolio committee on foreign affairs, in South African yearbook of international affairs / SAIIA, 2001-2002, p 97-104.

Tim Hughes. (2005). Strengthening Parliamentary Democracy in Southern Africa: country studies in South Africa Journal of International Affairs, v 12, no 1, Summer/Autumn 2005, p 11-236.

Tim Hughes. (2002). The Parliamentary Portfolio Committee on Foreign Affairs in SA Yearbook of International Affairs, 2001/02, p98-103.

Vincent Williams. (2001). South Africa's migration policy: an instrument of foreign policy (or not?) in South Africa yearbook of international affairs, 2000-01 / SAIIA, P 99-105.

William Bloom. (1990). Personal Identity, National Identity and International Relations Cambridge: Cambridge University Press.

William J Foltz. (1996). The foreign policy of the new South Africa in Conference Report on prospects of political and economic development... -- Monograph, 1996, P 389-409.

Zondi Masiza. (1999). Silent citizenry: public participation and foreign policy making, in CPS Policy Brief, no 15, Sep 1999, p 1-6. 